\title{
Hubungan antara Social Comparison dengan Self Esteem pada Alumni SMA/sederajat yang Menjalani Gap Year
}

\author{
IBRAHIM MUHAMMAD HANIFUDDIN \& RUDI CAHYONO* \\ Fakultas Psikologi Universitas Airlangga
}

\begin{abstract}
ABSTRAK
Penelitian ini bertujuan untuk mengetahui hubungan antara social comparison dengan self esteem pada alumni SMA/sederajat yang menjalani gap year. Self esteem adalah suatu evaluasi yang bersifat positif maupun negatif terhadap diri sendiri. Social comparison adalah proses saling memengaruhi dan saling bersaing dalam interaksi sosial karena kebutuhan individu untuk menilai diri sendiri yang dapat terpenuhi ketika individu membandingkan dirinya dengan orang lain. Pendekatan penelitian ini adalah pendekatan kuantitatif. Responden merupakan alumni SMA/sederajat, yang menjalani gap year yang berjumlah 190 orang. Seluruh responden mengisi skala Rosenberg Self Esteem Scale yang memiliki reliabilitas $=0,30$ dan mengisi skala Iowa Netherland Comparison Orientation Measure yang memiliki reliabilitas $=0,266$. Teknik sampling yang digunakan adalah simple random sampling. Teknik analisis yang digunakan adalah analisis korelasi Spearman melalui aplikasi Jamovi 1.6.8. Hasil ini penelitian ini adalah hubungan berkorelasi negatif dan bersifat lemah dengan Spearman's rho $=-0.232$ tetapi tetap memiliki signifikansi dengan $\mathrm{p}=0.001$
\end{abstract}

Kata Kunci: alumni sma/sederajat, gap year, self esteem, social comparison

\begin{abstract}
This study aims to see the relationship between social comparison and self-esteem in high school alumni who undergo a gap year. Self-esteem is an evaluation that is positive or negative towards oneself. Social comparison is the process of influencing and competing with others in social interactions because of the individual's need to assess themselves which can be fulfilled when individuals compare themselves. This research approach is a quantitative. Respondents 190 people of alumni of high school / equivalent, who have a gap year. All respondents fill in the Rosenberg Self Esteem Scale which has reliability=0.30 and fills in the Iowa Netherland Comparison Orientation Measure) scale which has reliability $=0.266$. The sampling technique was simple random sampling. The analysis technique is the Spearman with Jamovi 1.6.8. Results of this study: relationship is negatively correlated, has a weak character with Spearman's rho $=-0.232$ but still significance with $\mathrm{p}=0.001$.
\end{abstract}

Keywords: alumni of senior high school/equal, gap year, self esteem, social comparison

Buletin Penelitian Psikologi dan Kesehatan Mental (BRPKM), 2021, Vol. 1(1), 859-869

*Alamat korespondensi: Fakultas Psikologi Universitas Airlangga, Kampus B Universitas Airlangga Jalan Airlangga 4-6 Surabaya 60286. Surel: rudi.cahyono@psikologi.unair.ac.id

Naskah ini merupakan naskah dengan akses terbuka dibawah ketentuan the Creative Common Attribution License (CC-BY-4.0) (http://creativecommons.org/licenses/by/4.0), sehingga penggunaan, distribusi, reproduksi dalam media apapun atas artikel ini tidak dibatasi, selama sumber aslinya disitir dengan baik. 


\section{P E N D A H U L U A N}

Jenjang pendidikan yang dapat ditempuh pasca lulus SMA/sederajat adalah jenjang pendidikan di perguruan tinggi. Salah satu jenis perguruan tinggi yang diminati oleh alumni SMA/sederajat untuk menjadi tempat mengenyam pendidikan tinggi adalah perguruan tinggi negeri (PTN). Untuk menjadi mahasiswa di perguruan tinggi negeri, seorang alumni SMA/sederajat harus melalui proses seleksi. Berdasarkan keterangan yang diunggah di dalam situs jejaring Lembaga Tes Masuk Perguruan Tinggi (LTMPT), terdapat 2 jalur yang dapat diikuti oleh alumni SMA/sederajat untuk menjadi mahasiswa program sarjana di perguruan tinggi negeri, yaitu SNMPTN dan SBMPTN (Lembaga Tes Masuk Perguran Tinggi, 2020).

Seleksi Nasional Masuk Perguruan Tinggi Negeri atau yang disingkat dengan SNMPTN merupakan jalur masuk perguruan tinggi negeri yang dilakukan berdasarkan hasil penelusuran prestasi akademik dan/atau portofolio dari calon mahasiswa. Sementara itu, SBMPTN (Seleksi Besar Masuk Perguruan Tinggi Negeri) merupakan seleksi masuk perguruan tinggi negeri yang dilakukan berdasarkan hasil dari Ujian Tulis Berbasis Komputer (UTBK) yang mana UTBK tersebut terdiri atas Tes Potensi Skolastik (TPS), Tes Kompetensi Akademik (TKA), serta kriteria lain yang disepakati oleh PTN (Lembaga Tes Masuk Perguran Tinggi, 2020).

Dalam situs jejaring LTMPT, juga diunggah mengenai kuota dari daya tampung dalam SNMPTN, SBMPTN, dan Seleksi Mandiri. Dalam jalur SNMPTN, disediakan kuota daya tampung setiap program studi untuk calon mahasiswa baru dengan jumlah yang ditetapkan paling sedikit sebesar $20 \%$ dari setiap program studi. Sementara itu, dalam jalur SBMPTN, disediakan kuota daya tampung setiap program studi bagi calon mahasiswa baru ditetapkan paling sedikit dengan jumlah $40 \%$ dari setiap program studi. Dalam jalur Seleksi Mandiri, ditetapkan paling banyak 30\% dari setiap program studi bagi calon mahasiswa baru (Lembaga Tes Masuk Perguran Tinggi, 2020).

Jumlah peserta yang diterima di kedua seleksi tersebut selalu lebih sedikit jika dibandingkan total jumlah peserta yang ada, baik mereka yang menggunakan jalur reguler maupun jalur khusus seperti Bidikmisi dan KIP-Kuliah. Jumlah yang timpang antara jumlah peserta seleksi dan jumlah peserta yang lulus seleksi mengakibatkan munculnya jumlah peserta seleksi yang tidak lulus seleksi.

Ketika seseorang tidak lulus SNMPTN dan SBMPTN, terdapat beberapa opsi yang diambil oleh para alumni SMA/sederajat. Opsi-opsi tersebut di antaranya adalah mengikuti Seleksi Mandiri PTN, mengikuti Seleksi Perguruan Tinggi Kedinasan, mengikuti seleksi Perguruan Tinggi Swasta, bekerja, melakukan gapyear, maupun melakukan aktivitas atau kegiatan setelah dinyatakan tidak lulus SNMPTN maupun SBMPTN.

Pada zaman sekarang ini, gap year menjadi salah satu opsi yang dipilih oleh alumni SMA/sederajat di Indonesia ketika dinyatakan tidak lulus SNMPTN maupun SBMPTN. Berikut ini adalah beberapa definisi dan penjelasan mengenai gap year yang didapatkan dari berbagai macam literatur, baik yang berbentuk jurnal atau artikel berita, baik yang berasal dari Indonesia maupun luar negeri.

American Gap Year Assosiation (2012) mendefinisikan gap year sebagai periode waktu yang terstruktur ketika seorang pelajar mengambil waktu jeda dari pendidikan formalnya untuk meningkatkan selfawarness, belajar dari budaya yang berbeda dan bereksperimen dengan berbagai kemungkinan karir. Biasanya hal-hal tersebut dicapai melalui kegiatan seperti bekerja, magang, bepergian, dan menjadi 
sukarelawan. Pengalaman dari gap year sendiri biasanya mengambil waktu antara 2 bulan sampai 2 tahun yang mana waktu tersebut diambil setelah kelulusan sekolah menengah dan sebelum tahun awal jenjang pendidikan mereka yang lebih tinggi (Wellons, 2013).

Heath, seperti dicantumkan dalam Stehlik (2010), tertulis bahwa Departemen Pendidikan dan Keahlian Britania Raya mendefiniskan gap year sebagai waktu ketika sesseorang keluar dari pendidikan formalnya dan kemudian mengambil waktu antara 3 sampai 24 bulan yang mana waktu ini berada di dalam konteks lintasan karir yang lebih panjang (Wellons, 2013).

Jones (2004) dan Heath (2005) mengatakan bahwa di Britania Raya kegiatan yang biasa dilakukan ketika seseorang menjalani gap year adalah belajar, bepergian, menjadi sukarelawan, serta bekerja (Curtis dkk., 2012). Sementara itu, di Amerika Serikat, waktu gap year bisa dilakukan dengan mengikuti organisasi berbasis gap year di sana seperti AmeriCorps ataupun bekerja untuk Habitat for Humanity. Organisasi relawan internasional pun juga menjadi salah satu opsi pilihan yang tersedia untuk memberi tempat kepada para orang-orang yang menjalani gap year untuk menjadi relawan di berbagai belahan dunia. Program imersi budaya dan bahasa pun juga hadir untuk memfasilitasi para gap year dalam rangka memenuhi pencapaian mereka untuk fasih dalam bahasa lain. Selain itu, terdapat pula programprogram lain yang tersedia mulai dari berpergian dalam petualangan hingga mengajar bahasa Inggris di luar negeri (Wellons, 2013).

Sejalan dengan berbagai hal yang sudah dijelaskan pada paragraf sebelumnya, Haryanti pada tahun 2019 telah menuliskan bahwa terdapat beberapa manfaat yang bisa diperoleh bagi alumni SMA/sederajat yang melakukan gap year. Manfaat tersebut di antaranya: menjadi lebih dewasa, menemukan minat, dan menambah pengalaman (Haryanti, 2019). Artikel lain yang ditulis oleh Wahyu Adityo Prodjo di Kompas.com dengan judul "4 Manfaat Gap Year, Salah Satunya Belajar Mandiri dari Orangtua" juga menuliskan beberapa manfaat yang dapat diperoleh ketika seseorang mengambil kesempatan untuk gap year. Beberapa manfaat tersebut di antaranya: masa untuk mendewasakan diri, mengenal diri lebih dalam, membuka mata dan wawasan baru, serta melatih hidup mandiri (Prodjo, 2020b).

Meskipun begitu, ketika seseorang memutuskan untuk melakukan gap year, terdapat beberapa kerugian yang ternyata dapat diperoleh. Berdasarkan artikel yang juga ditulis oleh Wahyu Adityo Prodjo di Kompas.com dengan judul "3 Kerugian Gap year, Bisa Bikin Malas dan Keluarin Banyak Uang", kerugian yang dapat dialami oleh seseorang ketika melakukan gap year di antaranya: tak siap belajar secara formal, mengeluarkan banyak biaya, dan stigma negatif gap year (Prodjo, 2020a).

Masih berhubungan dengan yang diutarakan oleh Prodjo dalam artikelnya, Wellons juga memiliki pernyataan yang tidak jauh berbeda di dalam jurnalnya. Ia mengatakan bahwa terdapat banyak program, perjalanan, dan juga aktivitas yang bisa memiliki nilai finansial yang sangat mahal ketika dilakukan oleh orang yang menjalani gap year, sekalipun uang yang dikeluarkan bisa sangat terjangkau karena tergantung dari kegiatan atau program apa yang akan diambil (Wellons, 2013).

Wellons juga mengatakan dalam jurnalnya bahwa potensi yang dapat muncul pada masa gap year yang dijalani oleh individu akan menjadi masa yang sia-sia, meskipun tentunya masih terdapat potensi bahwa motivasi dalam diri individu akan meningkat selama menjalani masa gap year. Yang mungkin memiliki kekhawatiran terbesar bagi seorang individu yang menjalani gap year adalah orang tua, guru, dan juga konselor di sekolah. Mereka khawatir jika seorang siswa mengambil masa jeda dari sekolah, siswa tersebut mungkin tidak akan kembali untuk menjalani proses pembelajaran secara akademik (Wellons, 2013). 
Sejalan dengan hal tersebut, penulis telah membuat sebuah survei kecil kepada beberapa alumni SMA/sederajat yang sedang menjalani gap year yang tersebar di berbagai daerah Indonesia melalui internet. Penulis memberikan pertanyaan-pertanyaan yang berhubungan dengan gap year kepada responden. Pertanyaan yang paling penulis gunakan dalam survei ini adalah: Apa permasalahan terbesar yang kamu alami selama menjalani gap year? (Hanya boleh dijawab dengan satu kalimat singkat).

Pertanyaan tersebut bertujuan untuk mengetahui permasalahan terbesar yang dihadapi oleh responden. Jawaban terbanyak dari pertanyaan inilah yang akan digunakan oleh penulis untuk menentukan variabel Y dalam penelitian. Penulis memperoleh responden sebanyak 18 orang.

Dari hasil survei singkat penulis, permasalahan dengan jumlah paling tinggi adalah permasalahan mengenai penilaian diri. Permasalahan dengan jumlah terbesar kedua adalah permasalahan bersosialisasi. Permasalahan dengan jumlah terbesar ketiga adalah permasalahan aktivitas pribadi. Setelah itu, disusul permasalahan belajar. Permasalahan berikutnya adalah permasalahan manajemen waktu yang memiliki jumlah penjawab yang sama dengan yang menjawab tidak ada masalah. Berdasarkan hasil survei, dapat disimpulkan bahwa masalah yang memiliki jumlah paling besar adalah permasalahan penilaian diri.

Dalam istilah Psikologi, penilaian diri dapat disebut sebagai self esteem. Menurut Rosenberg pada tahun 1965 yang tercantum dalam Mruk (2006), self esteem merupakan evaluasi diri yang dilakukan secara global, baik itu secara positif maupun secara negatif (Nurhidayati \& Nurdibyanandaru, 2014). Sementara itu, Bednar, Wells, dan Peterson (1989) mengatakan bahwa self esteem adalah umpan balik yang bersifat subjektif tentang seberapa memadai dari diri (Leary, 2010).

Terindentifikasinya self esteem sebagai masalah terbesar yang dialami oleh alumni SMA/sederajat yang menjalani gap year terlihat dari jawaban-jawaban yang diberikan oleh responden yang memberikan penilaian yang negatif dan rendah terhadap diri mereka sendiri yang mana hal tersebut berhubungan dengan kondisi yang dialami oleh mereka saat ini, yaitu belum menjadi mahasiswa di perguruan tinggi manapun. Seperti yang sudah disebutkan di paragraf sebelumnya, masalah ini juga menjadi masalah yang disebut oleh responden dalam survei singkat ini.

Hal ini sejalan dengan apa yang dikatakan oleh Bednar, Wells, dan Peterson pada tahun (1989) bahwa penelitian telah menunjukkan self esteem yang rendah berhubungan dengan berbagai permasalahan psikologis dan juga permasalahan pribadi yang mencakup depresi, kesepian, kegagalan akademik, perilaku kriminal, dan penyalahgunaan zat (Leary, 2010).

Selain melakukan survei kecil, penulis juga melakukan wawancara singkat dengan empat orang alumni SMA/sederajat yang menjalani gap year. Para peserta gap year yang diwawancara adalah terdiri atas 1 orang yang mengikuti bimbingan belajar kelas alumni SMA/sederajat di Kabupaten Sidoarjo dan 3 orang yang mengikuti bimbingan belajar kelas alumni SMA/sederajat di Kota Surabaya. Alasan dilakukannya wawancara di kedua tempat tersebut adalah kedekatan antara tempat bimbingan belajar dengan tempat tinggal penulis di Surabaya. Dari hasil wawancara tersebut, juga ditemukan permasalahan yang berhubungan dengan penilaian diri dan bersosialisasi yang dihadapi oleh para alumni SMA/sederajat yang sedang menjalani gap year.

Jawaban yang didapatkan dari penulis ketika melakukan wawancara dengan mereka adalah bahwa mereka merasa diremehkan, merasa dianggap sebagai orang yang gagal, merasa dibanding-bandingkan dengan teman-teman mereka dan orang lain yang sudah kuliah, merasa iri melihat teman-temannya yang berkuliah, minder dengan teman sebaya mereka, merasa insecure, merasa paling tidak bisa apa- 
apa, dan ingin mudah menyerah. Jika disimpulkan, berdasarkan hasil wawancara yang dilakukan, pokok permasalahan terbesar yang dihadapi oleh para alumni SMA/sederajat adalah permasalahan mengenai penilaian diri. Permasalahan penilaian diri tersebut berhubungan dengan keadaan diri para partisipan wawancara yang belum menjadi mahasiswa sementara teman-temannya sudah menjadi mahasiswa.

Menurut Bednar, Wells, dan Peterson, pada tahun (1989), penelitian telah menunjukkan bahwa self esteem yang rendah berhubungan dengan berbagai permasalahan psikologis dan juga permasalahan pribadi yang mencakup depresi, kesepian, kegagalan akademik, perilaku kriminal, dab penyalahgunaan zat. Masih menurut Leary, faktor-faktor yang dapat menurunkan self esteem di antaranya adalah kegagalan, kritik, penolakan, dan momen-momen lain yang memiliki dampak negatif terhadap evaluasi relasional. Sementara itu, self esteem akan meningkat ketika seseorang mengalami kesuksesan, mendapatkan pujian, atau mengalami pengalaman yang menyenagkan lainnya yang mana hal tersebut merupakan kejadian yang berhubungan dengan apresiasi relasional (Leary, 2010).

Salah satu kasus yang berhubungan dengan fenomena ini adalah sebuah berita yang dimuat oleh suarajogja.id yang berjudul "Tiga Tahun Tunda Kuliah, Gadis ini Menangis Tersendu Gagal Kuliah di UNY". Dalam berita tersebut, dijelaskan bahwa telah beredar sebuah video yang memperlihatkan seorang gadis yang menangis setelah dirinya 3 tahun menunda kuliah dan kemudian gagal diterima di Universitas Negeri Yogyakarta atau yang biasa disingkat sebagai UNY (Priatmojo, Galih; Maulina, 2020).

Video tersebut berasal dari akun TikTok dengan @milkytee yang dibagikan oleh akun Instagram @Jogja24Jam. Dalam video tersebut, terlihat sang gadis yang menangis tersedu ketika melihat hasil pengumumannya sambil ia menutup kedua matanya. Matanya juga terlihat sembab bercucuran air mata dan hidungnya memerah yang juga disertai dengan wajahnya basah. Saat ia menggeser kepalanya, sang gadis menunjukkan hasil pengumuman yang menyatakan bahwa ia tidak lulus dalam mengikuti seleksi mandiri S1 melalui jalur prestasi akademik (Priatmojo, Galih; Maulina, 2020).

Selain itu, melalui keterangan yang tercantum, disampaikan bahwa gadis ini sudah menunda kuliahnya selama 3 tahun. Tahun ini, ia mencoba untuk mendaftar salah satu perguruan tinggi negeri di Daerah Istimewa Yogyakarta, yaitu Universitas Negeri Yogyakarta. Meskipun begitu, ia belum juga diterima di perguruan tinggi negeri tersebut (Priatmojo, Galih; Maulina, 2020). Contoh tersebut juga memperlihatkan bagaimana ketika seseorang yang sudah 3 tahun menjalani gap year menjadi sedih setelah gagal diterima di Universitas Negeri Yogyakarta.

Dari fakta-fakta yang sudah ditampilkan, terlihat bahwa terdapat permasalahan yang dihadapi oleh alumni SMA/sederajat yang menjalani gap year. Berdasarkan hal tersebut, masalah yang banyak terjadi pada alumni SMA/sederajat yang menjalani gap year adalah masalah dalam self esteem yang mereka miliki. Hal ini terjadi karena kegagalan yang mereka lalui ketika mengikuti seleksi masuk perguruan tinggi negeri. Seperti yang sudah dikatakan oleh Leary (2010), salah satu faktor yang dapat menurunkan self esteem adalah kegagalan, yang menurut Bednar, Wells, dan Peterson pada tahun (1989) penelitian juga telah menunjukkan bahwa self esteem yang rendah memiliki hubungan dengan kegagalan akademik (Leary, 2010).

Selain itu, menurut Rosenberg (1965), terdapat dua hal yang berperan dalam pembentukan self-esteem, yaitu reflected appraisals dan social comparisons (Srisayekti \& Setiady, 2015). Menurut Festinger (1954), social comparison merupakan suatu proses saling mempengaruhi dan saling bersaing dalam interaksi sosial yang timbul karena adanya kebutuhan individu untuk menilai diri sendiri yang mana kebutuhan 
tersebut dapat terpenuhi ketika individu membandingkan dirinya dengan orang lain (Puspitasari \& Ambarini, 2017). Perilaku social comparison ini sangat mungkin terjadi pada alumni SMA/sederajat yang menjalani gap year.

Kemungkinan terjadinya social comparison disebabkan oleh keadaan mereka yang belum kuliah karena gagal mengikuti seleksi perguruan tinggi, sementara teman-teman mereka menjadi mahasiswa di perguruan tinggi, khususnya di peguruan tinggi yang gagal mereka masuki seperti peguruan tinggi negeri, peguruan tinggi kedinasan, maupun jenis perguruan tinggi lainnya sehingga akan ada kecenderungan dari mereka untuk melakukan social comparison kepada teman mereka yang sudah berkuliah. Ketika mereka melakukan social comparison, hal tersebut akan berdampak terhadap self esteem yang mereka miliki. Seperti yang sudah dijelaskan sebelumnya bahwa menurut Rosenberg pada (1965), salah satu yang berperan dalam proses pembentukan self esteem adalah social comparison (Srisayekti \& Setiady, 2015). Hal tersebut dapat terlihat dari hasil survei singkat dan wawancara yang dilakukan oleh penulis bahwa selain permasalahan self esteem sebagai permasalahan terbesar yang mereka alami, mereka juga memiliki permasalahan dalam bersosialisasi, khususnya ketika mereka minder, iri, insecure, membandingkan-bandingkan, maupun perilaku-perilaku lainnya yang berhubungan dengan social comparison terhadap teman-teman mereka yang sudah terlebih dahulu berkuliah.

Terdapat sebuah hasil penelitian yang dilakukan oleh Hasanati dan Aviani yang berjudul Hubungan Social Comparison dengan Self Esteem pada Pengguna Instagram. Mereka melakukan penelitian terhadap dewasa awal yang menjadi pengguna instagram di Kota Bukittinggi, Sumatra Barat. Dari hasil penelitiannya, ditemukan bahwa terdapat yang signifikan antara social comparison dengan self esteem dan hubungan tersebut memiliki koefisien korelasi yang bernilai negatif (Hasanati \& Aviani, 2020).

Oleh karena itu, selain self esteem yang menjadi variabel Y, variabel terikat, atau variabel dependen dalam penelitian ini, dipilihlah social comparison sebagai variabel $\mathrm{X}$, variabel bebas, atau variabel independen dalam penelitian ini. Tujuan dari adanya penelitian ini adalah untuk mengungkap hubungan yang terjadi antara social comparison dengan self esteem pada alumni SMA/sederajat yang menjalani gap year.

\section{E T O D E}

Tipe dalam penelitian ini menggunakan pendekatan kuantitatif. Menurut Neuman, ciri-ciri penelitian kuantitif di antaranya adalah: peneliti menguji hipotesis yang dicantumkan di bagian awal penelitian, konsep penelitian berupa variabel yang berbeda, Pengukuran disusun secara sistematis sebelum pengumpulan data dan sudah distandardisasi, data berbentuk angka yang berasal dari pengukuran yang tepat, teori yang digunakan sebagian besar bersifat kausal dan deduktif, prrosedur bersifat standar dan sering terjadi replikasi, dan analisis dilakukan melalui statistik, tabel, atau grafik yang kemudian hasil analisisnya dibahas dengan apa yang tercantum di dalam hipotesis penelitian(Djamba \& Neuman, 2002)

Sementara itu, dalam melakukan proses pengambilan data, metode yang digunakan adalah metode survei. Menurut Neuman, survei merupakan penelitian kuantitatif yang mana peneliti secara sistematis bertanya kepada banyak orang mengenai pertanyanan-pertanyaan yang sama yang kemudian jawaban dari pertanyaan-pertanyaan tersebut dicatat oleh peneliti (Djamba \& Neuman, 2002).

Partisipan dalam penelitian ini adalah alumni SMA/sederajat yang menjalani gap year. Alumni SMA/sederajat yang dimaksud di sini adalah mereka yang telah menamatkan pendidikan SMA/sederajat yang kemudian menjalani gap year setelah mereka lulus SMA. Karena mereka sedang menjalani gap year, tentunya alumni SMA/sederajat ini bukanlah mereka yang pernah menjadi 
mahasiswa di peguruan tinggi manapun. Selain itu, alumni SMA/sederajat ini adalah mereka yang berencana untuk melanjutkan pendidikan mereka ke perguruan tinggi setelah mereka menjalani gap year.

Untuk melakukan sampling dalam pengambilan data di penelitian ini, jenis sampling yang akan dilakukan adalah random sampling, khususnya simple random sampling. Menurut Neuman, random sampling adalah jenis sampling yang menggunakan metode matematis acak sehingga setiap unsur sampel dari populasi memiliki kemungkinan untuk terpilih ke dalam sampel (Djamba \& Neuman, 2002). Sementara itu, kembali menurut Neuman, simple random sampling adalah suatu sampling yang dilakukan ketika menciptakan kerangka sampling dan menggunakan proses acak murni untuk memilih kasus sehingga setiap pengambilan elemen sampel dalam populasi akan memiliki probabilitas yang sama untuk dipilih sebagai sampel (Djamba \& Neuman, 2002).

Untuk melakukan pengujian terhadap hipotesis penelitian, penulis menyebarkan kuesioner kepada 190 partisipan (Musia=18,9; SDusia=12,3; 51,1 persen perempuan dan 48,9 persen laki-laki) yang memenuhi kriteria, yaitu mereka yang merupakan alumni SMA/sederajat, belum pernah menjadi mahasiswa di perguruan tinggi mana pun, dan berencana untuk kuliah.

Dalam melakukan pengukuran skala variabel Y, yang dalam hal ini adalah Rosenberg Self Esteem Scale (RSES), penulis melakukan penjumlahan dari hasil pengisian seluruh item yang dilakukan oleh partisipan dengan item 1, 2, 4, 6, dan 7 yang bersifat favorable dan item 3, 5, 8, 9, 10 yang bersifat unfavorable dan hasil pengisiannya harus dibalik terlebih dahulu sebelum dijumlahkan dengan hasil pengisian item-item favorable.

Dalam melakukan pengukuran skala variabel X, yang dalam hal ini adalah Iowa-Netherland Comparison Orientation Measure (INCOM), penulis melakukan penjumlahan dari hasil pengisian seluruh item yang dilakukan oleh partisipan dengan item 1, 2, 3, 4, 5, 7, 8, 9 dan 11 yang bersifat favorable dan item 6 dan 10 yang bersifat unfavorable dan hasil pengisiannya harus dibalik terlebih dahulu sebelum dijumlahkan dengan hasil pengisian item-item favorable.

Untuk skala RSES, skala yang digunakan terdiri atas pilihan jawaban 0 (Sangat Tidak Setuju), 1 (Tidak Setuju), 2 (Setuju), dan 3 (Sangat Setuju).

Untuk skala INCOM, skala yang digunakan terdiri atas pilihan jawaban 1 (Sangat Tidak Setuju), 2 (Tidak Setuju), (3Antara Tidak Setuju dan Setuju), 4 (Setuju), dan 5 (Sangat Setuju).

Dari uji normalitas yang menggunakan Shapiro-Wilk ini ditemukan bahwa nilai p dari variabel X dalam penelitian ini adalah sebesar 0,0009. Sementara itu, nilai p dari variabel Y dalam penelitian ini adalah kurang dari ,001. Nilai ini menunjukkan bahwa variabel X memiliki normalitas sementara variabel Y tidak memiliki normalitas.

Berdasarkan hasil penelitian Gómez-Lugo, dkk pada tahun 2016 yang meneliti adaptasi, validitas, realibilitas, dan faktor keseteraan dari Rosenberg Self Esteem Scale dalam populasi orang Kolombia dan orang Spanyol, Rosenberg Self Esteem Scale yang sudah diadaptasi ke dalam bahasa Spanyol Kolombia maupun bahasa Spanyol asli sudah reliabel dan memiliki nilai (value) yang sesuai dengan yang dianut di kedua negara tersebut dengan total korelasi dari item yang terkoreksi yang memiliki nilai lebih dari 0,30, kecuali untuk item nomor 8 dalam versi Kolombia (Gómez-Lugo et al., 2016).

Berdasarkan penelitian mengenai skala INCOM versi bahasa Rusia, ditemukan adanya reliabilitas dengan nilai $r$ sebesar 0,266 dari seluruh item dalam skala ini terhadap indikator orientasi 
perbandingan sosial yang terbukti dari hasil yang tidak berbeda antara hasil pengukuran pertama dengan hasil pengukuran berulang (Garanian, N.G.; Pushinka, 2016).

Analisis data dalam penelitian ini bertujuan untuk mengetahui hubungan antara social comparison dengan self esteem. Analisis yang akan digunakan adalah analisis statistik. Untuk melakukan analisis tersebut, akan digunakan salah satu dari aplikasi statistik yang beredar. Aplikasi statistik yang akan digunakan dalam analisis statistik ini adalah Jamovi.

Uji analisis yang akan digunakan adalah uji korelasi. Tujuan dari dilakukannya uji korelasi adalah untuk mengetahui ada atau tidaknya hubungan antara variabel social comparison dengan variabel self esteem dalam penelitian ini. Sebelum melakukan uji korelasi, dilakukan terlebih dahulu uji normalitas. Tujuan dari dilakukannya uji normalitas adalah untuk memastikan kenormalan dari data yang sudah diambil melalui survei. Ketika data sudah normal, data pun dapat dianalisis dan diberikan uji-uji lainnya.

Setelah uji normalitas yang kemudian menghasilkan data yang normal, uji yang dilakukan berikutnya adalah uji liniearitas. Uji ini bertujuan untuk mengetahui apakah lantara variabel X dalam penelitian ini, yaitu variabel social comparison, dengan variabel Y dalam penelitian ini, yaitu variabel self esteem bersifat linear atau tidak.

Dalam peneleitian ini, terdapat dua pilihan mengenai uji korelasi yang akan dilakukan. Pilihan yang pertama adalah dengan Uji Korelasi Spearman. Sementara itu, pilihan yang kedua adalah dengan Uji Korelasi Pearson. Pemilihan salah satu dari kedua uji ini bergantung kepada uji asumsi dari data penelitian. Dengan melakukan uji korelasi melalui salah satu dari uji tersebut, akan diketahui bagaimana hubungan antara variabel self esteem dan variabel social comparison serta seberapa signifikan hu bungan yang terjadi di antara kedua variabel tersebut.

\section{HAS I L P E N EL I T I A N}

\section{Hasil Uji Linearitas}

Setelah melakukan analisis regresi linier, model diketahui cocok dalam menjelaskan data $(p<0,001 ; R=$ 0,$\left.231 ; R^{2}=0.394\right)$. Social Comparison $(S E=0,0514 ; t=-3,26 ; p<0,001)$ berkorelasi negatif dan bersifat lemah dengan self esteem.

\section{Hasil Uji Korelasi}

Setelah dilakukan uji korelasi, diketahui bahwa social comparison berkorelasi negatif $(r(190)=-0,232$; $p<0.001$ ) dan cenderung bersifat lemah dengan self esteem.

\section{I S K U S I}

Penelitian ini berhasil mengumpulkan 190 responden dengan berbagai latar belakang yang berbeda baik itu jenis kelamin, usia, pendidikan terakhir, provinsi domisili, maupun yang lainnya. Dari hasil penelitian ini, ditemukan bahwa hubungan yang terjadi antara variabel $\mathrm{X}$ dengan variabel $\mathrm{Y}$ memiliki sifat yang berbanding terbalik, kekuatan yang lemah, tetapi tetap memiliki signifikansi.

Dalam uji normalitas, variabel X memiliki data yang normal, berbeda dengan variabel $\mathrm{Y}$ yang memiliki data yang tidak normal. Salah satu alasan dari terjadinya ketidaknormalan tersebut adalah terdapat kemungkinan bahwa banyak responden yang kebingungan ketika mengisi nomor 8 dalam skala Self Esteem yang bersifat unfavorable yang berbunyi sebagai berikut: "saya berharap dapat lebih menghargai

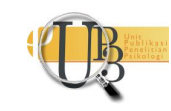


diri saya." Kebingungan tersebut mungkin terjadi karena nomor tersebut dianggap sebagai pernyataan yang bersifat positif. Anggapan tersebut mungkin muncul karena adanya kesalahan dalam proses penerjamahan skala yang memang pada awalnya menggunakan bahasa Inggris.

Kenormalan variabel X terjadi karena memang salah satu problematika yang terjadi pada alumni SMA/sederajat yang menjalani gap year adalah masalah social comparison yang kemudian berujung kepada permasalahan self esteem. Perilaku social comparison terjadi karena individu sedang tidak kuliah sementara teman-teman sebayanya kuliah. Perilaku social comparison akan lebih mungkin terjadi jika penyebab individu tidak kuliah adalah karena gagal mengikuti seleksi masuk perguruan tinggi.

Perilaku tersebut juga didukung oleh perkembangan teknologi, khususnya internet dan media sosial. Ketika individu yang tidak kuliah, apalagi karena gagal ketika mengikuti seleksi masuk perguruan tinggi, melihat foto dan video yang diunggah oleh temannya yang berkuliah, akan ada kemungkinan bahwa perilaku social comparison individu meningkat. Hal itu tentunya akan berujung kepada penurunan self esteem individu.

Hubungan yang berkorelasi negatif terjadi karena memang sesuai dengan teori yang menyatakan bahwa ketika social comparison meningkat, self esteem akan menurun dan ketika social comparison menurun, self esteem akan meningkat. Selain itu, signifkansi yang ditemukan juga sesuai dengan teori yang mengatakan bahwa terdapat hubungan yang terjadi antara social comparison dengan self esteem.

Lemahnya hubungan yang terjadi di antara variabel X dan variabel Y dalam penelitian ini mungkin terjadi karena ketidaknormalan variabel self esteem yang sebab-sebabnya sudah disebutkan sebelumnya. Selain itu, berdasarkan pemaparan tabel hasil skoring, responden dengan frekuensi tertinggi ternyata adalah mereka yang memiliki skor self esteem sedang yang kemudian disusul di posisi kedua oleh responden yang memiliki skor self esteem tinggi, dan diakhiri oleh mereka yang memiliki skor self esteem rendah dengan frekuensi terkecil.

Jumlah skor self esteem responden dengan frekuensi dan persentase seperti ini tentunya memengaruhi kuat atau lemahnya hubungan yang terjadi antara social comparison dengan self esteem karena seperti yang sudah disebut sebelumnya, bahwa self esteem diakibatkan oleh social comparison yang tinggi dan berlaku sebaliknya. Hal ini sangar berlawanan dengan hasil penelitian ini yang memperlihatkan bahwa mayoritas responden memiliki skor self esteem sedang dan tinggi jika digabungkan tetapi mayoritas responden juga memiliki skor social comparison yang agak tinggi, tinggi, dan sangat tinggi jika digabungkan.

Penyebab lemahnya hubungan antara variabel $\mathrm{X}$ dan $\mathrm{Y}$ dalam penelitian ini mungkin juga terjadi karena banyaknya responden yang merupakan alumni SMK dengan persentase sebesar 16,8\% dari total responden. Alumni SMK memiliki orientasi kehidupan yang sedikit berbeda setelah lulus dari sekolah mereka jika dibandingkan dengan para alumni SMA dan MA.

Alumni SMK dituntut untuk lebih siap masuk ke dunia kerja setelah mempelajari berbagai ilmu yang sesuai dengan kejuruan mereka sehingga orientasi hidup mereka setelah lulus sekolah mungkin juga lebih memprioritaskan untuk bekerja jika dibandingkan untuk kuliah. Hal itu berbeda dengan alumni SMA dan MA yang memang diharapkan untuk masuk perguruan tinggi setelah lulus dari SMA dan MA yang menjadi tempat mereka bersekolah.

Selain itu, dari total seluruh responden yang ada, terdapat 20,5\% dari total responden yang mengaku sedang bekerja ketika proses pengambilan data penelitian ini berlangsung. Ketika seorang bekerja, sangat mungkin orientasi hidupnya untuk kuliah menjadi berkurang sehingga melanjutkan pendidikan 
di perguruan tinggi bukan menjadi tujuan utama setelah lulus dari SMA/sederajat. Hal itu disebabkan karena mungkin individu sudah sibuk bekerja dan sudah merasa puas karena dapat memperoleh penghasilan sendiri sehingga tidak menjadikan kuliah sebagai tujuan utama.

Pandemi Covid-19 juga mungkin memberikan pengaruh. Dengan adanya pandemi Covid-19, terjadi pengurangan aktivitas di luar rumah dan peningkatan aktivitas di dalam rumah yang dilakukan oleh beberapa orang. Pola aktivitas seperti ini membuat pengurangan pertemuan langsung dengan orang lain yang tentunya juga akan memberikan pengaruh kepada social comparison yang berujung kepada pengaruh terhadap self esteem yang dimiliki oleh individu.

\section{S I M P U L A N}

Dari hasil penelitian ini, ditemukan adanya hubungan antara social comparison dengan self esteem pada alumni SMA/sederajat yang menjalani gap year. Hubungan yang terjadi adalah berkorelasi negatif, yaitu peningkatan social comparison akan mengakibatkan penurunan self esteem dan penurunan social comparison akan mengakibatkan penurunan self esteem. Meskipun begitu, hubungan yang terjadi bersifat lemah karena berbagai hal yang terjadi selama proses penelitian ini.

\section{UCAPAN TERIMAKASIH}

Penulis mengucapkan terima kasih yang sebesar-besarnya kepada Bapak Eka Purbaya, S.Psi. dan Ibu Diana Mardiahayati, M.Psi., Psikolog yang bersedia menjadi rater terhadap skala yang digunakan dalam penelitian ini. Penelitian juga mengucapkan terima kasih yang sebesar-besarnya kepada Alif Zidan Muhammad, S.S. selaku pengoreksi skala terjemahan yang digunakan oleh penulis. Tak lupa pula penulis mengucapkan terima kasih yang sebesar-besarnya kepada seluruh responden survei awal, wawancara awal, hingga kuesioner penelitian yang serta berbagai lembaga bimbingan belajar yang sudah memberikan bantuannya kepada penulis untuk menyebarkan kuesioner penelitian penulis.

\section{DEKLARASI POTENSI TERJADINYA KONFLIK KEPENTINGAN}

Ibrahim Muhammad Hanifuddin dan Rudi Cahyono tidak bekerja, menjadi konsultan, memiliki saham, ataupun menerima dana dari perusahaan atau organisasi manapapun yang mungkin akan mengambil keuntungan dari penerbitan naskah ini.

\section{PUSTAKA ACUAN}

American Gap Year Association. (2012). Data \& Gap Year Benefits. American Gap Year Association.

Bednar, R.L., Wells, M.G., Peterson, S. R. (1989). Paradoxes and innovations in clinical theory and practice. American Psychological Association.

Curtis, D. D., Mlotkowski, P., \& Lumsden, M. (2012). Bridging the gap: Who takes a gap year and why? Longitudinal Surveys of Australian Youth - Research Reports, 59(1).

Djamba, Y. K., \& Neuman, W. L. (2002). Social Research Methods: Qualitative and Quantitative

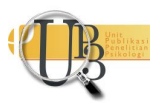


Approaches. In Teaching Sociology (Vol. 30, Issue 3). https://doi.org/10.2307/3211488

Festinger, L. (1954). A Theory of Social Comparison Processess. SAGE Social Science Collection, 1(1).

Garanian, N.G.; Pushinka, E. S. (2016). ESTABLISHING VALIDITY AND RELIABILITY OF THE RUSSIAN VERSION OF THE IOWA-NETHERLANDS COMPARISON ORIENTATION MEASURE IN STUDENT'S SAMPLE. Counseling Psychology and Psychotherapy, 64-92.

Gómez-Lugo, M., Espada, J. P., Morales, A., Marchal-Bertrand, L., Soler, F., \& Vallejo-Medina, P. (2016). Adaptation, validation, reliability and factorial equivalence of the rosenberg self-esteem scale in colombian and Spanish population. Spanish Journal of Psychology, 19, 1-12. https://doi.org/10.1017/sjp.2016.67

Haryanti, R. (2019). Tak Lolos SBMPTN? Coba Ambil "Gap Year"! Kompas. https://edukasi.kompas.com/read/2019/07/16/17511521/tak-lolos-sbmptn-coba-ambil-gapyear?page $=$ all

Hasanati, U., \& Aviani, Y. I. (2020). Hubungan social comparison dengan self-esteem pada pengguna instagram. Jurnal Pendidikan Tambusai, https://jptam.org/index.php/jptam/article/view/721

Heath, S. (2005). The pre-university gap year: a research agenda, Gap Year working paper.

Jones, A. (2004). Review of gap year provision.

Leary, M. R. (2010). Sense of Self-Esteem. 8(1), 32-35.

Lembaga Tes Masuk Perguran Tinggi. (2020). Penerimaan Mahasiswa Baru. LTMPT. https://ltmpt.ac.id/?mid=5\#a1

Mruk, C. J. (2006). Self esteem research, theory and practice.

Nurhidayati, N., \& Nurdibyanandaru, D. (2014). Hubungan Antara Dukungan Sosial Keluarga dengan Self Esteem pada Penyalahguna Narkoba yang Direhabilitasi. Psikologi Kepribadian Dan Sosial, 3(2), 52-59.

Priatmojo, Galih; Maulina, M. R. (2020). Tiga Tahun Tunda Kuliah, Gadis Ini Menangis Tersedu Gagal Kuliah di UNY. Suarajogja.Id. https://jogja.suara.com/read/2020/09/15/135659/tiga-tahuntunda-kuliah-gadis-ini-menangis-tersedu-gagal-kuliah-di-uny

Prodjo, W. A. (2020a). 3 Kerugian Gap Year, Bisa Bikin Malas dan Keluarin Banyak Uang. Kompas. https://edukasi.kompas.com/read/2020/02/02/20490291/3-kerugian-gap-year-bisa-bikinmalas-dan-keluarin-banyak-uang

Prodjo, W. A. (2020b). 4 Manfaat Gap Year, Salah Satunya Belajar Mandiri dari Orangtua. Kompas. https://edukasi.kompas.com/read/2020/02/02/20041841/4-manfaat-gap-year-salah-satunyabelajar-mandiri-dari-orangtua?page $=2$ 
Puspitasari, A. I., \& Ambarini, T. K. (2017). Hubungan Social Comparison dan Body Dissatisfaction pada Remaja Perempuan. Jurnal Psikologi Klinis Dan Kesehatan Mental, 6, 59-66.

Rosenberg, M. (1965). Society and the adolescent self-image. Princeton University Press.

Srisayekti, W., \& Setiady, D. A. (2015). Harga-diri (Self-esteem) Terancam dan Perilaku Menghindar. Jurnal Psikologi, 42(2), 141. https://doi.org/10.22146/jpsi.7169

Stehlik, T. (2010). Mind the gap: School leaver aspirations and delayed pathways to further and higher education. Journal of Education and Work, 23(4), 363-376.

Wellons, S. (2013). Give Me a Break: A Study of the Gap Year. Honors Senior Theses/Projects. http://digitalcommons.wou.edu/honors_theses/86 